\title{
KH Domain-Containing, RNA-Binding, Signal Transduction-Associated Protein 1
}

National Cancer Institute

\section{Source}

National Cancer Institute. KH Domain-Containing, RNA-Binding, Signal Transduction-

Associated Protein 1. NCI Thesaurus. Code C102429.

KH domain-containing, RNA-binding, signal transduction-associated protein 1 (443 aa, $\sim 48 \mathrm{kDa}$ ) is encoded by the human KHDRBS1 gene. This protein is involved in signaling pathway modulation and the mediation of alternative RNA splicing that regulates apoptosis. 